\title{
LITURGIA SZCZYTEM I ŹRÓDŁEM MODLITWY UCZNIÓW CHRYSTUSA W KOŚCIELE STAROŻYTNYM
}

DOI: http://dx.doi.org/10.12775/TiCz.2021.007

Streszczenie. Myśl przewodnią artykułu stanowi kwestia relacji, jaka powinna zachodzić pomiędzy liturgią i modlitewną pobożnością prywatną chrześcijan. Sobór Watykański II zdefiniował liturgię jako szczyt, do którego ma prowadzić wszystko, czym Kościół żyje na co dzień, oraz jako źródło, które zasila wciąż nową energią jego życie i działanie. Naukę tę sobór - przez umiejętny powrót do źródeł - wydedukował z przebogatej Tradycji Kościoła, osadzonej na skale, którą jest Jezus, następnie zaś - począwszy od chrześcijańskiej starożytności - mozolnie utwierdzanej i gruntowanej przez pokolenia wierzących w Chrystusa. Choć proces owego utwierdzania i gruntowania Tradycji Kościoła trwa nieprzerwanie i dosięga czasów nam współczesnych, to treść artykułu skupia naszą uwagę jedynie na najbardziej pierwotnym jego etapie, a więc na chrześcijańskiej starożytności, czyli na dziejach Kościoła apostolskiego (okres pokrywający się mniej więcej z I wiekiem), w trakcie których treść owej Tradycji była dopiero i jeszcze konstytuowana, oraz na najstarszej fazie dziejów Kościoła poapostolskiego (okres od II do początków V wieku), w trakcie której treść Tradycji apostolskiej zaczęła być (i jest wciąż) przez Kościół zachowywana.

Słowa kluczowe: liturgia; liturgia godzin; modlitwa nieustanna; modlitwa prywatna; pobożność; pory dnia i nocy.

Abstract. The Liturgy as the Summit and Source of Prayer for the Disciples of Christ in the Ancient Church. The main theme of the article is the relationship that should exist between the liturgy and the private devotion of Christians. The Second 
Vatican Council defined the liturgy as the summit to which everything that the Church lives every day should lead and as the source that constantly nourishes her life and activity. Through a skilful return to the sources, the Council deduced this teaching from the rich Tradition of the Church - set on the rock that is Jesus and then, starting from Christian antiquity, laboriously consolidated and grounded by generations of believers in Christ. Although this process of consolidation and grounding of the Church's Tradition has persisted without interruption until our present day, the article focuses our attention solely on the earliest stage, that is on Christian antiquity or, in other words, the history of the Apostolic Church (i.e. the period roughly coinciding with the first century), when the content of this Tradition was still being constituted, and on the earliest stage of the history of the post-Apostolic Church (i.e. the period from the second century to the beginning of the fifth century), when the content of the Apostolic Tradition began to be preserved by the Church (as it still is today).

Keywords: liturgy; liturgy of the hours; continuous prayer; private prayer; piety; times of day and night.

Prawdą jest, że naukę o liturgii jako o szczycie, do którego zmierza działalność Kościoła, i jednocześnie o źródle, z którego wypływa cała jego moc, zdefiniował i klarownie wyłożył Sobór Watykański II (zob. KL 10), który odbył się w latach 1962-1965. Wypada jednak pamiętać o tym, że zapoczątkowana przez tenże sobór reforma, mająca na celu dostosowanie życia Kościoła do współczesnych czasów, do sytuacji, w jakiej znalazł się i żyje świat, a w nim Kościół, nie straciła kontaktu z żywą Tradycją Kościoła. Przeciwnie, pragnęła dzieło odnowy jego życia i działalności oprzeć na samych korzeniach tejże Tradycji. Czas bowiem trwania soboru był nade wszystko czasem powrotu do źródeł, a więc próbą odczytania na nowo owej żywej Tradycji, która kształtowała Kościół przez wieki, począwszy od czasów apostolskich ${ }^{1}$. Dlatego pragnieniem autora poniższego studium jest wspomożenie czytelnika w duchowym przeniesieniu się do czasów starożytnych, w których owa przebogata dziś Tradycja Kościoła stawiała pierwsze kroki. Pragnienie takie tłumaczy się faktem, że jednym z paradoksów katolicyzmu jest to, iż jego „nowoczesność tkwi w nawrocie do źródeł”2.

1 Por. G. Ginter, Odnowa w Kościele. Rozważanie oparte na adhortacjach apostolskich Jana Pawła II, http://mateusz.pl/mt/10lat/gg-owk.htm (dostęp: 22.08.2020).

2 P. Sczaniecki, Msza po staremu się odprawia, Tyniec-Kraków 2009², s. 216. 
Być może znajdzie się ktoś, w kim zrodzi się pytanie, po co cofać się do czasów przeszłych - i to tak odległych, sięgających chrześcijańskiej starożytności? Odpowiedź wydaje się oczywista: warto studiować tamten okres, bo w nim właśnie zawiązało się życie Kościoła, w zarodku powstała liturgia i pozaliturgiczna pobożność modlitewna. Stąd pierwsi chrześcijanie - jako najbliżsi źródła - pozostają na zawsze uprzywilejowanymi świadkami pierwszych wydarzeń Kościoła, uznawanymi za autorytety, do których odnoszą się sobory i synody oraz teologowie, gdy przyjdzie im rozwiązywać lub interpretować kwestie teologiczno-pastoralne. To starożytni chrześcijanie z Pismem Świętym w ręku i z dźwięczącym w uszach głosem Chrystusa pokazali, jak modlić się na Jego wzór i jak zgodnie z Jego wolą sprawować oraz kształtować ustanowioną przez Niego liturgię̧.

Taki jest powód, dla którego w tytule niniejszego artykułu zamieszczone zostały dwa kluczowe dla jego treści pojęcia, które brzmią: „liturgia” i „modlitwa”. Spontaniczną reakcją na takie zestawienie owych pojęć może być pytanie o ich znaczeniową zbieżność lub przeciwstawność. Do refleksji nad taką kwestią może pobudzać dość popularne i często samorzutnie stawiane przez niektórych chrześcijan pytanie, czy konieczną jest rzeczą uczestniczenie w niedzielnej Mszy świętej, a więc w sercu liturgii, bo być może wystarczyłoby - jak twierdzą - pomodlić się indywidualnie bądź wspólnotowo we własnym mieszkaniu, w plenerze, bądź w jakimś innym jeszcze miejscu. Niedawno kard. Raymond Leo Burke, wspominając pierwszy okres swojej kapłańskiej posługi, która miała miejsce w latach 70. XX wieku, zwracał uwagę na fakt, jak to niektórzy z ówczesnych ludzi krytycznie się odnosili do obowiązku uczestniczenia w niedzielnej Mszy, tłumacząc przy tym, że z Panem Jezusem może człowiek wierzący spotkać się i rozmawiać z Nim w lesie, nad rzeką lub w innym miejscu tzw. łona przyrody ${ }^{4}$.

Gdy dziś, u progu trzeciej dekady XXI wieku, obserwujemy szczególnie w zachodniej części Europy (chociaż chyba nie tylko tam) - zjawisko pustoszenia kościołów w niedzielę i święta obowiązujące, to

3 Por. M. Starowieyski, Dlaczego Kościół starożytny?, https://teologiapolityczna.pl/ marek-starowieyski-dlaczego-kosciol-starozytny\#_ftnref1 (dostęp: 14.03.2020).

${ }^{4}$ Por. Kard. Burke krytykuje teologiczne błędy „Querida Amazonia”, https:// www.fronda.pl/a/kard-burke-krytykuje-teologiczne-bledy-querida-amazonia,141247.html (dostęp: 12.03.2020). 
mimowolnie ciśnie się na usta pytanie o poprawność rozumienia i zrównoważonego, a więc adekwatnego w stosunku do siebie praktykowania z jednej strony liturgii (szczególnie niedzielnej Mszy), z drugiej zaś indywidualnej pobożności w chrześcijańskim życiu, często sprowadzającej się do modlitewnych praktyk. Spora część współczesnych chrześcijan chętnie dziś bierze udział w różnego rodzaju wydarzeniach mniej lub więcej religijnych. Bywa jednak, że pewien procent uczestników takich wydarzeń po powrocie do codzienności nie odczuwa wzmożonego pragnienia zmiany w podejściu do liturgii, niejednokrotnie dotąd słabo przeżywanej lub wręcz zaniedbywanej, choć zapotrzebowanie na pogłębioną refleksję czy medytację, na indywidualną modlitwę (może częściej i jakoś inaczej niż dotąd praktykowaną) albo na pewien szczególny rodzaj pobożności indywidualnej daje o sobie znać u niektórych z nich.

Problemem więc istotnej wagi jest kwestia racjonalnego i poprawnego traktowania oraz przeżywania proporcji, jakie powinny być w życiu chrześcijan zachowywane $\mathrm{w}$ przeżywaniu liturgii - z Eucharystią na czele - oraz pobożności pozaliturgicznej, której znaczącą część stanowią zróżnicowane formuły modlitewne. $\mathrm{W}$ zachowywaniu takich proporcji powinien nas wspomagać nade wszystko, choć oczywiście nie wyłącznie, przykład chrześcijan okresu starożytnego ${ }^{5}$, jako że "przywilejem” chrześcijan czasów apostolskich i poapostolskich ${ }^{6}$ było nadawanie kształtu

${ }^{5}$ Epoka starożytności chrześcijańskiej to pierwsze kilkaset lat dziejów Kościoła. Chrześcijaństwo zrodziło się w Palestynie i związane było w swoich początkach z kręgiem kultury izraelskiej. Rychło jednak zaczęło się szerzyć wśród pogan, wiążąc chrystianizm w sposób nieodwracalny z kulturą grecko-rzymską i wprowadzając go u zarania IV wieku w sojusz z cesarstwem rzymskim. Stopniowy rozkład tego cesarstwa i ostateczny jego upadek, spowodowany najazdem ludów barbarzyńskich, wyznaczyły koniec pierwszej epoki dziejów Kościoła, zwanej starożytną (zob. D. Olszewski, Dzieje chrześcijaństwa $w$ zarysie, Katowice 1982, s. 12; Starożytność, w: Nowa encyklopedia powszechna PWN, t. VI: $S-Z$, red. B. Petrozolin-Skowrońska, Warszawa 1997, s. 31).

${ }^{6}$ Chrześcijanie czasów apostolskich tworzyli tzw. Kościół apostolski (pierwotny) uformowany przez pierwotną wspólnotę wyznawców Chrystusa. W sensie właściwym Kościół ten utożsamiany był z gminą jerozolimską, czyli środowiskiem wyznawców Chrystusa skupionych wokół grona apostołów od dnia zesłania Ducha Świętego do rozproszenia gminy jerozolimskiej w wyniku najazdu Tytusa na Jerozolimę w 70 roku. W znaczeniu szerszym pojęcie to odnoszone było do wszystkich wspólnot chrześcijańskich na terenie Azji Mniejszej i Palestyny, a nawet do wszystkich wspólnot chrześcijań- 
wszystkim obszarom organizującego się w mocy Ducha Świętego Kościoła, powierzonego przez Chrystusa bezpośredniej pieczy apostołów, po nich zaś ich następców.

\section{LITURGIA I POZALITURGICZNE PRAKTYKI MODLITEWNE W ŻYCIU JEZUSA ORAZ KOŚCIOŁA APOSTOLSKIEGO}

Zjawisko stosownych proporcji $\mathrm{w}$ sprawowaniu liturgii oraz pozaliturgicznych form modlitewnej pobożności stanowi swoisty fenomen wyznawców Chrystusa od czasów apostolskich. Wyznawcy ci bowiem, a więc członkowie Chrystusowego Kościoła, począwszy od Jerozolimy aż po nasze czasy, trwają - zgodnie ze świadectwem Dziejów Apostolskich - „w łamaniu chleba [czyli sprawują Eucharystię] i w modlitwach” (Dz 2,42). Oprócz Eucharystii zaczęli na polecenie Jezusa udzielać również sakramentu chrztu i umocnienia Duchem Świętym, jak też - wraz z upływem czasu - pozostałych, znanych nam i przyjmowanych przez nas sakramentów. Z biegiem czasu zaczęli członkowie Kościoła celebrować również liturgię godzin i sakramentalia, jak też zachowywać stopniowo kształtujący się na przestrzeni wieków rok liturgiczny. Tak formowała się liturgia, nad którą Kościół roztacza z woli Chrystusa swoją pieczę, sprawuje ją i nią kieruje. Obok liturgii specyficzną i zależną od różnych czynników żywotnością cieszą się także zróżnicowane i kultywowane na przestrzeni poszczególnych etapów rozwoju kultu chrześcijańskiego formy

skich powstałych w I wieku po Chrystusie lub w czasach ojców apostolskich, czyli do połowy II wieku (por. E. Gigilewicz, Kościół pierwotny, w: Encyklopedia katolicka, t. IX, red. B. Migut, Lublin 2002, kol. 1052). Stąd tradycję powstałą w czasach apostolskich zwie się w teologii konstytutywną, bo ma się na uwadze fakt, iż treść Objawienia Bożego w Chrystusie (ukształtowana w czasach apostolskich i przez apostołów jako tych, którzy byli bezpośrednimi świadkami Chrystusowego dzieła Objawienia) stanowi dla Kościoła „źródłowy” element konstytutywny i regulujący późniejsze formułowanie treści przekazywanego Objawienia, czyli tradycji kościelnej okresu poapostolskiego. Różnica między Kościołem apostolskim i poapostolskim polega nie na głoszeniu odmiennego orędzia, lecz na tym, że treść tradycji w Kościele apostolskim była dopiero i wciąż jeszcze konstytuowana, a w Kościele poapostolskim ma ona być respektowana i zachowywana (por. A. Lewek, Objawienie Boże a ewangelizacja według Vaticanum II, „Studia Theologica Varsaviensia" 31 [1993] nr 2, s. 159, 177). 
pobożności pozaliturgicznej. Jedno i drugie, a więc liturgia i kult pozaliturgiczny, zachowywane i przestrzegane w odpowiednich proporcjach, stały się dla uczniów Chrystusa istotne, ważne i potrzebne.

1.1. KOŚCIÓk, SPRAWUJĄC LITURGIĘ, NAŚLADUJE JEZUSA I WYPEKNIA JEGO WOLE

Wiadomą jest rzeczą, że zamiłowanie do liturgii i do modlitwy wynieśli pierwsi wyznawcy Chrystusa, a więc pierwotni chrześcijanie, ze swoich pobożnych żydowskich rodzin, z których się wywodzili. Dla tych rodzin - zgodnie z tradycją jerozolimską - udział w świątynnej liturgii, którą należy uznać za typ liturgii eucharystycznej chrześcijan, z czasem zaś także w liturgii synagogalnej, stanowiącej z kolei typ liturgii słowa u chrześcijan, jak też codzienna i w odpowiednich porach doby odmawiana modlitwa, jako prawzór sprawowanej przez Kościół liturgii godzin, tworzyły podstawowe filary religijnego życia rodzin żydowskich ${ }^{7}$.

Niezależnie jednak od tego, że pierwsi chrześcijanie kontynuowali religijne zwyczaje Żydów, ich życie liturgiczno-duchowe oraz modlitwę naznaczyło decydująco wydarzenie Jezusa, który m.in. w przypowieści o tym, że „zawsze powinni modlić się i nie ustawać” (Łk 18,1), kreślił przed nimi horyzonty modlitwy nieustannej i domagając się jej od nich, dając im jednocześnie przykład częstego modlenia się. Na tymże przykładzie Jezusa próbowali wzorować się ci, którzy odpowiadali na Jego wezwanie i Go naśladowali (por. Łk 18,22). Tych, którzy się Nim fascynowali i za Nim faktycznie szli, uczył modlitwy. Uczył ich jej jednak nie tylko słowem, lecz nade wszystko własnym sposobem modlenia się (por. KKK 2607), jako że z codzienną Jego działalnością złączona była ściśle modlitwa, która głęboko tę działalność przenikała. Jezus więc uczestniczył podczas swego ziemskiego życia w modlitwach publicznych - w świątyni, którą nazywał domem modlitwy (Mt 21,13; Łk 19,46) ${ }^{8}$, a także w syna-

${ }^{7}$ Por. M. Kunzler. Liturgia Kościoła (Amateca: Podręczniki teologii katolickiej 10), tłum. i oprac. L. Balter, Poznań 1999, s. 533.

8 Wyrażenie „Mój dom ma być nazwany domem modlitwy” osnute jest na tle nauki proroków: „Cudzoziemców [...], którzy się przyłączyli do Pana [...] przyprowadzę na moją świętą górę i rozweselę w moim domu modlitwy” (Iz 56,6-7). Jeremiasz czyni 
gogach, do których się udawał w soboty „zgodnie ze swoim zwyczajem” $\left(\right.$ Łk 4,16) ${ }^{9}$.

Kiedy natomiast nadeszła „Jego godzina” (por. J 2,4), zasiadł z uczniami do stołu, by spożyć ostatnią wieczerzę, która nie utożsamiała się $\mathrm{w}$ sensie dosłownym $\mathrm{z}$ żadnym określonym obrzędem żydowskim, lecz była czymś nowym, a mianowicie była i pozostaje po wszystkie czasy zbawczą ofiarą Nowego Testamentu, przypieczętowaną przelaniem Krwi Chrystusa na krzyżu. Ostatnia wieczerza więc była sakramentalnie dokonanym wydaniem się Jezusa jako prawdziwego Baranka na śmierć, wydaniem ustanawiającym Jego własną Paschę ${ }^{10}$ - nie na zasadzie jakoby $\mathrm{Mu}$ zależało na zniesieniu dawnych rzeczy, lecz na doprowadzeniu ich do pełnego znaczenia i urzeczywistnienia ${ }^{11}$. W tym bowiem celu przyszedł On na świat - nie po to, by znieść wszystko, co było do tej pory, ale by to wypełnić (por. Mt 5,17). Stąd „Jego Pascha” nie przewidywała zastosowania skrupulatnie wszystkich elementów dotychczasowego święta Paschy, obchodzonego przez Żydów co roku ${ }^{12}$. Jezusowi wystarczyły tylko niektóre $\mathrm{z}$ nich, a mianowicie chleb, wino i słowo objaśnienia oraz modlitwy ${ }^{13}$. Znamienne natomiast, całkiem nowe i zobowiązujące wszystkich

swym rodakom wyrzut, że dopuszczają się zabójstw, cudzołóstwa, krzywoprzysięstwa; palą kadzidło ku czci Baala, a potem przychodzą do świątyni, aby czuć się bezpiecznie i nadal pełnić występki (Jr 7,8-10). Na koniec zadaje im pytanie: „Może jaskinią zbójców stał się w waszych oczach ten dom, nad którym wzywano mojego imienia?” (Jr 7,11). O częstym przebywaniu w świątyni i nauczaniu wspomina Jezus w momencie pojmania Go w Ogrodzie Getsemani: „Codziennie zasiadałem w świątyni i nauczałem, a nie pochwyciliście Mnie” (Mt 26,55; Mk 14,49; Łk 22,53).

9 O wystąpieniach Jezusa w synagogach wspomina Łk 4,44 („,głosił słowo w synagogach Judei”) oraz Mk 1,39: „Chodził po całej Galilei, nauczając w ich synagogach i wyrzucając złe duchy".

${ }^{10}$ Por. J. Ratzinger/Benedykt XVI, Jezus $z$ Nazaretu, cz. II: Od wjazdu do Jerozolimy do Zmartwychwstania, Kielce 2006, s. 126.

11 Por. tamże, s. 127.

${ }^{12}$ Na centralny obchód tej Paschy, jaki stanowiła wieczerza paschalna, składały się za czasów Jezusa cztery następujące części: spożywanie wstępnych potraw, liturgia paschalna (odmawianie psalmów), właściwa wieczerza oraz liturgia końcowa. Por. J. Jeremias, Die Abendmahlsworte Jesu, Göttingen $1967^{4}$, s. 79 nn.; A. Gerken, Teologia Eucharystii, tłum. S. Szczyrbowski, Warszawa 1977, s. 22.

${ }_{13}$ Por. A. Gerken, Teologia Eucharystii, s. 23-24; A. Żądło, Pascha Jezusa i jej uobecnienie w liturgii, w: Quod itaque Redemptoris nostri conspicuum fuit, in sacramenta 
wyznawców Chrystusa stało się polecenie przekazane Kościołowi, aby to, czemu On dał początek było czynione na Jego pamiątkę (por. Łk 22,19; 1 Kor 11,24). Stąd pierwszoplanowym zadaniem Kościoła jest właśnie „Czynienie”, czyli sprawowanie ustanowionej przez Chrystusa liturgii, z Eucharystią na czele, bo ona jest „źródłem i zarazem szczytem całego życia chrześcijańskiego" (KK 11). Z Eucharystią wiążą się bowiem inne sakramenty, kościelne posługi i dzieła apostolstwa, a jednocześnie wszystkie one ku Eucharystii zmierzają i nas wierzących prowadzą (por. KKK 1324). W taki to sposób ustanowiona przez Chrystusa liturgia z Eucharystią na czele wyprzedza wszystkie inne praktyki kultyczno-pobożnościowe wierzących i ogniskuje je w sobie, stanowiąc - zgodnie z określeniem Soboru Watykańskiego II - szczyt i źródło wszystkiego, co Kościół stanowi i czemu on poświęca swą misyjną służbę w świecie i dla świata (por. KL 10).

\subsection{KOŚCIÓŁ CZERPIE Z MODLITEWNYCH PRAKTYK JEZUSA}

Oprócz wzmiankowanych wyżej modlitw publicznych w świątyni czy w synagodze, odznaczających się typicznym znamieniem nowotestamentalnej liturgii słowa i liturgii eucharystycznej, Jezus w swej ziemskiej misji, uprzedzającej Jego zbawczą Paschę i do niej prowadzącej, modlił się - podobnie jak pobożni Izraelici - według swego ludzkiego serca, praktykował codzienne modlitwy, których w pierwszej kolejności nauczył się z pewnością od swojej Matki, Maryi, skupionej modlitewnie na zachowywaniu i rozważaniu w sercu wielkich spraw Boga (zob. Łk 1,49; 2,19.51 - por. KKK 2599).

Jezus praktykował także tradycyjne błogosławieństwa przy posiłkach (por. Mt 14,19; 15,36; Mk 8,6), zanosił prośby do Tego, który mógł Go wybawić - i był wysłuchiwany (Hbr 5,7) ${ }^{14}$, modlił się rano (por. Mk 1,35 ) oraz wieczorem (por. Mk 6,46-47), znał też modlitwy popołudniowe

transivit. Sakramenty w misterium Kościoła. Księga dedykowana Księdzu Profesorowi Czesławowi Krakowiakowi z okazji siedemdziesiątych urodzin, red. B. Migut, Z. Głowacki, W. Pałęcki, Lublin 2014, s. 71.

${ }^{14}$ Por. Ogólne wprowadzenie do Liturgii Godzin, w: Liturgia Godzin. Codzienna modlitwa ludu Bożego, t. I: Okres Adwentu. Okres Narodzenia Pańskiego, Poznań 2006, nr 4 (s. 24-26). 
(por. Łk 18,9-14; Dz 3,1). Ich praktykowanie naznaczone było typicznym znamieniem nowotestamentalnej liturgii godzin. Z tej Jezusowej, zainspirowanej modlitewną obrzędowością Izraela praktyki, ugruntowanej tradycją modlitwy Kościoła apostolskiego, pogłębionej i odpowiednio teologicznie uzasadnionej w okresie poapostolskim, zrodził się jeden z komponentów chrześcijańskiej liturgii, który gwarantuje modlitwę nieustającą - tę mianowicie, o którą chodziło Chrystusowi.

Innym i specyficznym rodzajem modlitwy Jezusa były długie, $\mathrm{w}$ odosobnieniu prowadzone $\mathrm{z}$ Ojcem rozmowy (por. Mk 1,35; 6,46; Łk 5,16; 6,12), do których często dochodziło w porze nocnej (por. Mk 1, 35; 6,46-48; Łk 6,12-13). Poza tym Pan modlił się przed decydującymi chwilami wyboru i powołania Dwunastu (por. Łk 6,12), modlił się też za Piotra, aby nie ustała wiara głowy apostołów w czasie kuszenia (por. $Ł k$ 22,32). Modlitwa Pana przed zbawczymi wydarzeniami to przykład pokornego i ufnego powierzania się woli miłującego Ojca (por. KKK 2600).

Gdy nadeszła godzina, w której Jezus miał wypełnić zamysł miłości Ojca, zaczął wyrażać niezmierzoną głębię swojej synowskiej modlitwy i to nie tylko przed dobrowolnym ofiarowaniem siebie (Łk 22,42), lecz także na krzyżu, a więc tam, gdzie modlitwa i oddanie zlały się całkowicie w jedno. To stamtąd wzniosły się do Ojca następujące słowa modlitwy Jezusa: „Ojcze, przebacz im, bo nie wiedzą, co czynią” (Łk 23,34); „Zaprawdę, powiadam ci: Dziś ze Mną będziesz w raju” (Łk 23,43); „Niewiasto, oto syn Twój [...] Oto Matka twoja” (J 19,26-27); „Pragnę” (J 19,28); „Boże mój, Boże mój, czemuś Mnie opuścił?” (Mk 15,34; por. Ps 22,2); „Wykonało się" (J 19,30); „Ojcze, w Twoje ręce powierzam ducha mojego” (Łk 23,46), aż do owego „donośnego wołania”, z którym umierał, oddając ducha (por. Mk 15,37; J 19,30b - zob. KKK 2605).

\subsection{KOŚCIÓł NA WZÓR JEZUSA SPRAWUJE LITURGIĘ, NAUCZA O MODLITWIE I PRAKTYKUJE JĄ W CODZIENNYM ŻYCIU}

Wspomniany wyżej fragment Dziejów Apostolskich $(2,42)$ poświadcza fakt, że członkowie pierwszej gminy kościelnej od samego początku dochowywali wierności Chrystusowemu powołaniu, sprawując ustanowioną i powierzoną im przez Niego liturgię sakramentów, z Eucharystią - „łamaniem chleba” - na czele, jak też organizując i wcielając 
w czyn przenikającą codzienne życie modlitwę, szczególnie tę liturgiczną, sprawowaną „nie przypadkowo i bezładnie, lecz w określonych [...] godzinach"15, na której treść składała się modlitwa Pańska, jakiej na prośbę samych apostołów nauczył ich Pan (por. Łk 11,1) ${ }^{16}$, odmawiana trzy razy dziennie wraz z doksologią ${ }^{17}$, a później również psalmy ${ }^{18}$.

Nie tylko jednak to, lecz Kościół pierwotny - znów za przykładem Jezusa - zaczął innych uczyć modlitwy, która dla niego była jednym $\mathrm{z}$ podstawowych filarów (obok trwania $\mathrm{w}$ nauce apostołów, łamaniu chleba i we wspólnocie - por. Dz 2,46-47) codziennego życia. Kościół tamtych czasów wyraźnie zachęcał do modlenia się, czego klasycznym przykładem stało się nawoływanie św. Pawła do modlitwy wytrwałej i nieprzerwanej, a więc zanoszonej do Boga w dzień i w nocy (por. $\mathrm{Rz}$ 12,12). Znamienne jest wzywanie kierowane przez Apostoła Narodów do chrześcijan o gorliwość na modlitwie. W słowie skierowanym do Kolosan posłużył się on zwrotem te proseuche proskartereite, który w dosłownym tłumaczeniu wskazuje na wierne zachowywanie jakiegoś obrzędu. Staje się zatem jasne, że już w tamtych czasach jawić się zaczęły pewne zręby dzisiejszej modlitwy liturgicznej, zapowiadające praktykowanie regularnego gromadzenia się na modlitwę. W trakcie takich zgromadzeń modlono się także za apostołów (por. Kol 4,2-3).

Znamienne jest również to, że w księgach Nowego Testamentu odnajdujemy wzmianki o modlitwie odbywanej poza porządkiem modlitw publicznych, a więc o modlitwie prywatnej. Na taki fakt wskazuje sam Jezus w przypowieści o faryzeuszu i celniku (por. Łk 18,9-14), którzy przyszli do świątyni. Każdy Żyd mógł udawać się tam o dowolnej porze dnia, aby się modlić lub złożyć ofiarę całopalną, niezależnie od faktu, że odbywały się w niej dwa razy w ciągu dnia modlitwy publiczne: rano (nasza 9.00) i po południu (nasza 15.00), kiedy to zebrani na dziedzińcu

${ }^{15}$ Klemens Rzymski, List do Kościoła $w$ Koryncie XL,2, w: Pierwsi świadkowie (Biblioteka Ojców Kościoła 10), wstęp, przekład i oprac. M. Starowieyski, Kraków 2010, s. 69.

${ }_{16}$ Por. F. Gryglewicz, Komentarz do Dz 2,42-47, w: Komentarze biblijne do czytań mszalnych. Rok A, red. J. Homerski, Lublin 1981, s. 58.

17 Por. Didache VIII, w: Pierwsi świadkowie, s. 36.

18 Zob. R.F. Taft, La liturgia delle ore in oriente e occidente. Le origini dell'ufficio e il suo significato per oggi, Roma 2001, s. 32-33. 
wierni uczestniczyli w śpiewie psalmów wykonywanych przez lewitów ${ }^{19}$. Ten przykład modlitwy prywatnej dwóch ludzi w świątyni przywołał Pan Jezus po to, by swoich wyznawców uczulić na potrzebę pokory i pełnego miłości otwarcia na bliźnich, jak też świadomości, że jedynie Boża interwencja zapewnia nam świętość życia i że dobre czyny, które wykonujemy, są również Bożymi darami łaski ${ }^{20}$.

Do modlitwy osobistej zachęcał Jezus wiele razy swych uczniów i wyznawców. Klasycznym wezwaniem jest to zalecające modlitwę przy drzwiach zamkniętych, we własnej izdebce (por. Mt 6,5-6), wolną od gadulstwa i wielomówstwa (por. Mt 6,7), zdolną uchronić nas przed uleganiem pokusom (por. Mt 26,41). Chrystus wciąż oczekuje od chrześcijan modlitwy zanoszonej do Boga w każdym czasie (por. Łk 21,36), a więc nie tylko tej uskutecznianej w ustalonych ramach czasowych.

Wezwania Chrystusa do modlitwy znalazły w życiu pierwszych chrześcijan szeroki odzew. Oprócz tego, że gromadzili się oni - jak wspomniano wyżej - na „łamanie chleba”, to uczestniczyli też w modlitwach - tych w początkowej fazie sprawowanych w świątyni (por. Dz 4,46), choć też z pewnością w jakichś modłach towarzyszących im w codziennym życiu ${ }^{21}$. Na konkretny przykład modlitwy spontanicznej apostołów natrafiamy przy uzupełnieniu grona Dwunastu, po sprzeniewierzeniu się Judasza (por. Dz 1,24-25: „I tak się pomodlili: «Ty, Panie, znasz serca wszystkich, wskaż z tych dwóch jednego, którego wybrałeś, by zajął miejsce $\mathrm{w}$ tym posługiwaniu i $\mathrm{w}$ apostolstwie, któremu sprzeniewierzył się Judasz»"). Podobnie - spontanicznie - modlił się (na wzór samego Jezusa) kamienowany Szczepan, kiedy „osunął się na kolana, [i] zawołał [...]: «Panie, nie poczytaj im tego grzechu»" (Dz 7,60). Przeżywający różne trudności w pełnieniu misji ewangelizacyjnej apostołowie prosili chrześcijan o modlitwę za nich (por. Dz 8,24), co się tłumaczy tym, że każde miejsce uważane jest przez wyznawców Chrystusa za dobre na modlitwę do Boga (por. Dz 10,9: „Piotr [np.] wszedł na dach, aby się pomodlić”).

19 Zob. F. Mickiewicz, Ewangelia wedtug świętego Łukasza: rozdziały 12-24 (Nowy Komentarz Biblijny III/2), Częstochowa 2012, s. 262.

${ }^{20}$ Por. R. Rubinkiewicz, Komentarz do Łk 18,9-14, w: Komentarze biblijne do czytań mszalnych. Rok C, red. S. Łach, Lublin 1981, s. 199.

${ }^{21}$ Por. K. Romaniuk, A. Jankowski, L. Stachowiak, Komentarz praktyczny do Nowego Testamentu, t. I, Poznań-Kraków-Tyniec 1999, s. 609. 
Są takie teksty w Nowym Testamencie, które pozwalają nam uświadomić sobie zajmowaną przez uczniów Chrystusa postawę (np. klęczącą) podczas modlitwy („Piotr upadł na kolana i modlił się” - Dz 9,40; „Na wybrzeżu padliśmy na kolana i modliliśmy się” - Dz 21,5). Występuje też w Dziejach Apostolskich opis, w którym odróżnia się kult publiczny (leitourgounton) od modlitwy związanej z błogosławieństwem, jakiego udzielano tym, których wyprawiano na misję (zob. Dz 13,2-3). W greckiej wersji tego tekstu Dziejów Apostolskich jest mowa najpierw o sprawowaniu leitourgounton, czyli - w dosłownym przekładzie - o „wykonaniu czynności liturgicznych”, jako że źródłosłów przytoczonego pojęcia ukryty jest w czasowniku leitourgein, z którego wywodzi się nazwa „liturgia”22. Dopiero po takim spełnieniu liturgicznych czynności i zachowaniu postu oraz po adekwatnej do okoliczności modlitwie, doszło do udzielenia błogosławieństwa Barnabie i Szawłowi na ich specjalną misję, wyznaczoną im przez Ducha Świętego ${ }^{23}$.

\section{LITURGIA I PRAKTYKI MODLITEWNE W KOŚCIELE POAPOSTOLSKIM}

Kościół wszedł w okres poapostolski z mocnym nastawieniem na dochowanie wierności Jezusowi i Jego nauce, jak też na kontynuowanie tego, czego w kwestii czytelności oraz przejrzystości w relacjach pomiędzy formami liturgicznymi i pozaliturgicznymi praktykami modlitewnymi nauczył swych uczniów sam Chrystus własnym przykładem, jak też, co zdołał utrwalić Kościół apostolski. Odpowiedź wierzących w Chrystusa na biblijne wezwanie do modlitwy nieustannej, obejmującej całe ich

22 Zob. R.J. Dillon, Atti degli Apostoli, w: Nuovo grende commentario biblico, red. R.E. Brown, J.A. Fitzmyer, R.E. Murphy, Brescia 1997, s. 978.

${ }^{23}$ Por. tamże. Autor przywołanego tu komentarza do Dziejów Apostolskich wyklucza dopuszczaną przez niektórych myśl o obrzędzie święceń i zdecydowanie opowiada się za jakąś formą błogosławieństwa udzielonego w kontekście modlitwy i postu dwóm wskazanym przez Ducha Świętego z grupy sobie równych (oprócz Barnaby i Szawła byli w Kościele w Antiochii prorokami i nauczycielami również Szymon zwany Niger, Lucjusz Cyrenejczyk i Manaen - Dz 13,1). Zob. G. Schneider, Die Apostelgeschichte, Teil 2: Kommentar zu Kap. 9,1-28,31 (Herders theologischer Kommentar zum Neuen Testament 5), Freiburg im Breisgau-Basel-Wien 1982, s. 115. 
życie, stało się również dla tego okresu charakterystycznym ideałem. Wcielany był on w czyn równolegle do utrwalonej i potwierdzonej już na początku II wieku - chociażby przez namiestnika Bitynii Pliniusza Młodszego - praktyki regularnego gromadzenia się chrześcijan na Eucharystię w określonym dniu (niedziela) przed wschodem słońca i śpiewania na przemian pieśni (modlitwy eucharystycznej?) ku czci Chrystusa jako Boga oraz wyrzekania się zła w postaci kradzieży, rozbojów, cudzołóstwa czy fałszywej przysięgi (forma aktu pokutnego?) ${ }^{24}$.

\subsection{SPOSOBY NA WCIELANIE W CZYN WEZWANIA DO NIEUSTANNEGO ZJEDNOCZENIA Z BOGIEM}

Wzmiankowany ideał modlitwy nieustannej inspirował ówczesnych chrześcijan do utrwalenia procesu prowadzącego w kierunku uformowania się modlitwy godzin, a co za tym idzie, opracowania schematów poszczególnych oficjów, redakcji odpowiadających im ksiąg liturgicznych, a także postępującego wciąż naprzód stabilizowania się właściwych relacji pomiędzy modlitwą wspólnotową i indywidualną, czyli modlitwą uskutecznianą z indywidualnej potrzeby serca i tą przewidywaną do wspólnej recytacji, a rozłożoną na odpowiednie pory dnia oraz nocy. Modlitwa liturgiczna Kościoła, do jakiej ostatecznie doszło w kolejnych epokach chrześcijaństwa (szczególnie w wiekach IV-VI), stanowi - jak widać - wielkie świadectwo bogatej duchowości uczniów Chrystusa, kształtującej się na przestrzeni wieków ${ }^{25}$.

Ciekawe dla omawianego w tym opracowaniu zagadnienia i bardzo istotne jest świadectwo płynące z Tradycji Apostolskiej (III wiek), które zwraca uwagę na ówczesną, wykazującą związek z epoką apostołów liturgię, oraz wiąże poszczególne godziny modlitewne z paschalnymi wydarzeniami męki, śmierci i zmartwychwstania Chrystusa ${ }^{26}$. Oprócz

${ }^{24}$ Zob. Pliniusz do Trajana, w: Pierwsi świadkowie, s. 362.

25 Por. T. Bać, Początki liturgii godzin - modlitwa wspólnoty chrześcijańskiej w pierwszych wiekach, w: Liturgia uświęcenia czasu - rozumieć, aby lepiej uczestniczyć. Wykład liturgii godzin, red. J. Hadalski, Poznań 2017, s. 79.

${ }^{26}$ Opisuje to Robert F. Taft, w cytowanej już książce La liturgia delle ore in oriente e occidente. Le origini dell'ufficio e il suo significato per oggi (zob. s. 43-49). Przytacza on 
tego wskazuje też na relacje modlitwy indywidualnej do wspólnotowej, uprzytamniając wyższość tej drugiej, sprawowanej w kościele, do którego „każdy [chrześcijanin] winien się udawać”27.

Powyższe zalecenie potwierdza wiedzę znaną nam skądinąd, że mianowicie w okresie trzech pierwszych wieków historii Kościoła uwydatniły się dwie charakterystyczne cechy liturgicznej modlitwy chrześcijan. Pierwszą z nich było to, że stała się ona modlitwą hierarchicznie zorganizowanej wspólnoty lokalnej, gromadzącej się pod przewodnictwem biskupa, z udziałem prezbiterów i diakonów. Drugą cechą było to, że stała się ona modlitwą zanoszoną do Boga w różnych porach dnia i nocy. Taką codzienną, systematyczną i najczęściej wspólnotową modlitwę zaczęto traktować jako obowiązkową dla wszystkich ochrzczonych, choć zakładano również możliwość modlenia się „u siebie w domu”, a więc indywidualnie, kiedy nie przewidywano gromadzenia się wiernych na liturgiczną modlitwę w kościele lub gdy stosowna do modlitwy pora dnia zastawała kogoś „,w innym miejscu”, a więc poza domem - wtedy powinien był modlić się "do Boga w swoim sercu”"28. Oznacza to, że powinien był wznieść do Boga modlitwę „prywatną”, a więc spontaniczną, odpowiadającą temu, co $\mathrm{w}$ danym momencie podpowiadało mu serce.

Wypada w tym miejscu wyrazić opinię, że przytoczone wyżej wskazania Tradycji Apostolskiej wspomagają nas w przekonaniu, iż troska Kościoła czasów poapostolskich o liturgię i duchowe życie chrześcijan sprowadzała się nie tylko do tego, aby dochować wierności młodej jeszcze wtedy Tradycji Kościoła, by ją pogłębiać i utrwalać, ale też, by gruntować klarowność priorytetów w przeżywaniu liturgii i wszelkich pozaliturgicznych aktów pobożnościowych: liturgii na pierwszym miejscu - utożsamianej już wtedy z sakramentami, spośród których Eucharystia stała na czele, ale też z modlitwą, nabierającą coraz bardziej

również świadectwa innych autorów wzmiankowanego III wieku (Klemensa Aleksandryjskiego, Orygenesa, Tertuliana i Cypriana) na omawiany temat (por. tamże, s. 33-42).

${ }^{27}$ „Niech każdy przede wszystkim idzie [do kościoła] i rozważa [tam] w swoim sercu, co Bóg mówi [do niego] przez tego, kto poucza. Kto bowiem modli się w kościele, ten zwycięży przeciwieństwa dnia” (Hipolit Rzymski, Tradycja Apostolska, III/41, wstęp, przekład, komentarz H. Paprocki, „Studia Theologica Varsaviensia” 14 (1976) nr 1, s. 167.

28 Tamże. 
cech liturgiczno-wspólnotowego działania Kościołów lokalnych, hierarchicznie zorganizowanych.

\subsection{LITURGIA I NOWE FORMY CHRZEŚCIJAŃSKIEJ DUCHOWOŚCI}

Poza tym, co zostało podkreślone wyżej, ujawniać się zaczęło w epoce poapostolskiej przychylne patrzenie Kościoła na wykluwające się nowe formy naśladowania Chrystusa i odpowiadania na Jego powołanie oraz - co za tym szło - na inicjowanie nowych, dotąd nieznanych form chrześcijańskiej duchowości, w dużej mierze skoncentrowanej na przeżywanej w odosobnieniu kontemplacji Boga. W takim kontekście, przywoływany już wielokrotnie w tym opracowaniu ideał modlitwy nieustannej zsynchronizował się ze specyficznym stylem bycia tych, którzy się decydowali na odosobnienie, najczęściej odchodząc na pustynię i dając początek nowemu, anachoreckiemu (samotnemu) stylowi życia, przez nadanie mu formatu permanentnego przebywania $\mathrm{z}$ Bogiem, życia w Jego obecności, a więc życia mniszego ${ }^{29}$.

Wzmiankowane wcześniej potrzeby serca znajdowały w przypadku ludzi pustyni (mnichów) upust niekoniecznie i nie wyłącznie w modlitwie liturgicznej Kościoła. Obierany przez nich tryb życia w odosobnieniu sprzyjał nawiązywaniu z Bogiem więzi bezpośredniej, osobistego dialogu i spontaniczności w kreowaniu klimatu spotkania z Nim na modlitwie ${ }^{30}$.

29 Pierwsze udokumentowane formy życia w odosobnieniu powstały na przełomie III i IV wieku w Egipcie. Stamtąd ta forma życia przedostała się do Palestyny i Syrii, a następnie na Zachód, szczególnie na wyspy Morza Śródziemnego oraz odludne tereny Italii i Galii, gdzie na bazie anachoretyzmu narodziły się wspólnoty eremickie i - później - monastyczne, a więc cenobityczne, czyli zakładające życie we wspólnotach zakonnych, kierujących się określoną regułą zakonną, zobowiązanych do posłuszeństwa wobec przełożonego, wspólnego odmawiania modlitw i uczestniczenia w Eucharystii, jak też do wykonywania określonych prac na rzecz wspólnoty. Por. H. Ćwikliński, Anachoreci, w: Encyklopedia katolicka, t. I, red. F. Gryglewicz, R. Łukaszyk, Z. Sułowski, Lublin 1985, kol. 474-475; H.I. Marrou, Od prześladowań za Dioklecjana do śmierci Grzegorza Wielkiego (303-604), w: Historia Kościoła, t. I: Od początków do roku 600, red. J. Daniélou, H.I. Marrou, Warszawa 1986, s. 210.

${ }^{30}$ B. Stypułkowska, Perspektywy dla dziewic konsekrowanych żyjacych $w$ świecie wynikające z duchowości monastycznej, „Analecta Cracoviensia” 48 (2016), s. 201. 
Stąd charakterystycznym rysem ich duchowości stało się przyznanie uprzywilejowanego miejsca modlitwie, do której czuli się zobowiązani $\mathrm{w}$ większym stopniu niż inni chrześcijanie ${ }^{31}$. Życie modlitwy przekładało się więc $\mathrm{w}$ omawianej tu grupie chrześcijan na dwie następujące formy: na modlitwę liturgiczną (szczególnie w przypadku powstałych później - począwszy od Antoniego Pustelnika - wspólnot pustelniczych) oraz modlitwę prywatną ${ }^{32}$. Choć modlitwa liturgiczna nie była nigdy typowa jedynie dla jakiejś wybranej grupy, bo przynależy do całego Kościoła, to jednak dla chrześcijan żyjących na pustyni, a więc dla mnichów eremitów, stanowiła najdoskonalszy sposób na doświadczanie drogi prowadzącej do Boga. Taki jest powód, dla którego przeznaczali oni dużo czasu na taką modlitwę, odkrywając w niej przychodzącego do nich Boga ${ }^{33}$. Niemniej znaczną część swojego mniszego życia poświęcali modlitwie prywatnej. Ten prywatny rodzaj uprawianej przez nich modlitwy charakteryzował się szczególnie otwarciem na Pismo Święte, a także na dzieła Ojców Kościoła ${ }^{34}$.

Nie dziwi więc fakt, że impuls wysłany przez omawianą tu grupę chrześcijan, a także ekspansja i rozwój prezentowanej przez nią formy życia, nie tylko doprowadziły do powstania pierwszych wspólnot zakonnych w Europie, ale też stały się w wymiarze ogólnochrześcijańskim narzędziem sprzyjającym kultywowaniu dobrze pojętych i zachowywanych proporcji pomiędzy składowymi elementami chrześcijańskiej duchowości, dla której fundamentem od czasów Chrystusa i pierwotnego Kościoła są sakramenty, z Eucharystią na czele, oraz modlitwa mająca wydźwięk z jednej strony liturgiczny (modlitwa liturgiczna), z drugiej zaś pobożnościowy (modlitwa prywatna). Słuszność takiego wniosku potwierdza choćby zawarta w Konstytucjach Apostolskich (dziele z końca IV wieku) zachęta do tego, aby biskupi mobilizowali wszystkich członków swoich Kościołów lokalnych do gorliwego schodzenia się razem „W dzień zmar-

${ }^{31}$ Por. J. Leclercq, U źródeł duchowości Zachodu. Etapy rozwoju i elementy stałe (Źródła monastyczne 49), tłum. S. Sztuka, red. nauk. i posł. T.M. Gronowski, Kraków-Tyniec 2009, s. 350.

32 Zob. B. Stypułkowska, Perspektywy dla dziewic konsekrowanych, s. 201.

${ }^{33}$ Por. J. Leclercq, U źródeł duchowości Zachodu, s. 351.

${ }^{34}$ Por. tamże, s. 353. 
twychwstania Pana, w dzień Pański”35 na sprawowanie liturgii mszalnej, której dwie części są wyraźnie w tym dokumencie wyszczególnione i określone jako: msza katechumenów (pierwsza część) i msza wiernych (druga część) $^{36}$. Biskupi mieli też mobilizować swych wiernych do tego, by regularnie, codziennie rano i wieczorem przychodzili do kościoła oraz gromadzili się po domach, aby śpiewać psalmy ${ }^{37}$. Reszta codziennego ich życia miała być wypełniona świadomością obecności w nim Pana oraz różnego rodzaju spontanicznymi modlitwami osobistymi, czyli takimi, które nie posiadają określonych form, a przez to różnią się od modlitwy liturgicznej. Źródłem takich modlitw miały być osobiste przeżycia, które dotykają spraw wewnętrznych każdego człowieka. Modlitwy te wyrastać miały bezpośrednio $\mathrm{z}$ doświadczenia serca, choć nie powinny być utożsamiane jedynie z uczuciami czy nastrojami tych, którzy do modlitwy stawali. $\mathrm{W}$ modlitwach tu wzmiankowanych werbalizował się stan wewnętrzny prowadzących dialog z Bogiem i wypowiadał się przed Nim w konkretnych, spontanicznie dobieranych słowach, stwarzając przed nimi dużą możliwość improwizacji - tak trochę na wzór psalmisty bądź mistyka ${ }^{38}$.

35 Zob. Księga II: O biskupach, prezbiterach i diakonach 59,1, w: Konstytucje apostolskie oraz Kanony Pamfilosa $z$ apostolskiego synodu w Antiochii, Prawo kanoniczne św. Apostołów, Kary świętych Apostołów dla upadłych, Euchologion Serapiona (Synody i kolekcje praw 2), układ i oprac. A. Baron, H. Pietras, Kraków 2007, s. 74*.

${ }^{36}$ Dla zapoznania się ze strukturą liturgii mszalnej, prezentowaną przez Konstytucje Apostolskie, jak również z opisem tejże struktury zob. J.J. Janicki, Historia Eucharystii w pierwszych wiekach chrześcijaństwa w świetle wybranych źródeł (II-IV w.), „Textus et Studia” 4 (2015) nr 4, s. 113-124.

37 Zob. Konstytucje Apostolskie, Księga II,59,1, s. 74*, 76*. Z powyższego wynika, że prócz modlitwy indywidualnej oraz sprawowanej Eucharystii, Konstytucje Apostolskie wzywają do sprawowania dwóch celebracji modlitewnych każdego dnia: rano i wieczorem. Dla zapoznania się z ze schematem i opisem takich celebracji zob. M. Ławreszuk, Nabożeństwo chrześcijańskie w IV wieku na podstawie „Konstytucji Apostolskich”, „Elpis” 12 (2012), s. 146.

${ }^{38}$ Por. Z. Nabzdyk, Modlitwa - źródło i wyraz duchowości, w: Teologia duchowości katolickiej, red. W. Słomka, M. Chmielewski, J. Misiurek, A.J. Nowak, Lublin 1993, s. $134-135$. 


\section{WNIOSKI}

Przedstawione powyżej opracowanie skłania do wyartykułowania niektórych wniosków. Pierwszy z nich wskazuje na fakt, że w okresie, który przypadł na ziemską misję Jezusa, a następnie na kontynuującą tę misję działalność Jego uczniów i apostołów, ustabilizowały się właściwe proporcje między liturgią Chrystusa, w której liturgia starotestamentalna osiągnęła swą pełnię, a pozaliturgicznymi praktykami modlitewnymi. Liturgia ustanowiona przez Jezusa nie opierała się na jakimś nowym, zbliżonym do któregokolwiek z obowiązujących dotąd systemów rytualnych, ale na Osobie ${ }^{39}$ - na tej Osobie, która bez pomieszania łączy w sobie naturę boską i ludzką (por. KKK 481), a w związku z tym również wszystko, co czyni i czemu daje początek, naznacza znamieniem harmonii, współbrzmienia i właściwych proporcji.

Inny wniosek pragnie nam uprzytomnić to, że specyfiką okresu poapostolskiego w Kościele był ścisły i - przynajmniej w pierwszej jego fazie - bezpośredni jeszcze kontakt z apostołami Chrystusa, którzy przez cały niemal pierwszy wiek ${ }^{40} \mathrm{z}$ wielkim zaangażowaniem wypełniali powierzoną im przez Jezusa misję ewangelizacyjną. Czynili to przez świadectwo życia, głoszenie słowa Bożego i sprawowanie liturgicznych celebracji. Wszystko oscylowało wokół wydarzeń zbawczych, których epicentrum stały się: męka, śmierć i zmartwychwstanie Jezusa, sakramentalnie urzeczywistnione w Wieczerniku, w którym Jezus ustanowił swą Paschę i polecił ją składać na swoją pamiątkę (por. Łk 22,19; 1 Kor 11,25). Na wielką miłość Chrystusa, przypieczętowaną przelaniem krwi na krzyżu, zaczęli wierzący odpowiadać bezgraniczną miłością do Niego, przejawianą w codziennym życiu, skoncentrowanym na liturgicznym upamiętnianiu Jego zbawczego dzieła. Nie szczędzili czasu ani samych siebie dla Niego, chętnie i z pełną odwagą gromadzili się na regularnie celebrowaną Eucharystię, sprawowali/

39 Por. K. Porosło, Przestrzeń między palcami, https://www.naszczas.pl/duch/ przestrzen-miedzy-palcami/ (dostęp: 31.03.2020).

${ }^{40}$ Św. Jan apostoł i Ewangelista umarł - jako ostatni z bezpośrednich uczniów Jezusa - śmiercią naturalną (choć wg niektórych poniósł śmierć męczeńską) ok. 100 roku w Efezie (por. X. Léon-Dufour, Słownik Nowego Testamentu, przekł. i oprac. K. Romaniuk, Poznań 1981, s. 308). 
przyjmowali inne sakramenty i organizowali swe życie zgodnie rytmem wybijanym przez modlitwę liturgiczną, jaką w poszczególne godziny dnia i nocy kierowali do Boga we wspólnocie, bądź indywidualnie. Siła porywu wiary w Jezusa była w omawianym okresie tak mocna, że Jego wyznawcy pragnęli za wszelką cenę oddać Mu się w sposób doskonały, składając - dosłownie - w męczeństwie ofiarę z życia otrzymanego od Boga i w Chrystusie uświęconego.

Idea poświęcenia tak silnie zakorzeniła się w chrześcijanach okresu poapostolskiego, że również po ustaniu prześladowań wciąż inspirowała ich do ofiary, inaczej co prawda teraz Bogu składanej, bo utożsamianej z „permanentnym przebywaniem z Bogiem”, z życiem jakby „już” po stronie Boga, niezależnie od faktu przebywania „jeszcze” na ziemi. Dało to początek konteplacyjno-mistycznemu stylowi, który życie skoncentrowane w czasach pierwszej ewangelizacji (a więc w czasach apostolskich) na Eucharystii/sakramentach i liturgicznej modlitwie uskutecznianej w stosownych porach dnia oraz nocy, ubogacił o aspekt bezpośredniego i osobistego, spontanicznego i permanentnego dialogowania z Bogiem przez chrześcijan podejmujących często życie w samotności, by móc kierować swe spojrzenie tylko na Boga, swoje pragnienia tylko ku Bogu, by być przywiązanymi tylko do Niego, a więc by żyć w jedności z Bogiem na tyle, na ile to jest możliwe, aby szukać Go i kontaktować się z Nim na wszelki możliwy dla człowieka sposób - przez modlitwę wspólnotową oraz prywatną, przez medytację, posty i praktyki ascetyczne ${ }^{41}$. Wszystko to było przez uczniów Chrystusa okresu starożytności chrześcijańskiej realizowane i przeżywane z zachowaniem zasady komplementarności, a więc wzajemnego dopełniania się liturgii i modlitewnej pobożności pozaliturgicznej - z tym, że liturgia dzierżyła rangę szczytu i źródła dla owej pobożności. Oznacza to, że pozaliturgiczna pobożność modlitewna, jak sama nazwa wskazuje, ubogacała i uzupełniała liturgię, nie przejawiała natomiast tendencji do splatania się $\mathrm{z}$ nią w jedno.

${ }^{41}$ Por. Mnich. Rozmowa $z$ Dom Antoinem Forgeotem OSB, opatem seniorem Fontgomabault, rozm. P. Milcarek, „Christianitas” 70 (2017), s. 109. 


\section{BIBLIOGRAFIA}

Bać T., Początki liturgii godzin - modlitwa wspólnoty chrześcijańskiej w pierwszych wiekach, w: Liturgia uświęcenia czasu - rozumieć, aby lepiej uczestniczyć. Wykład liturgii godzin, red. J. Hadalski, Hlondianum, Poznań 2017, s. 79-84.

Ćwikliński H., Anachoreci, w: Encyklopedia katolicka, t. I, red. F. Gryglewicz, R. Łukaszyk, Z. Sułowski, Towarzystwo Naukowe Katolickiego Uniwersytetu Lubelskiego, Lublin 1985, kol. 474-475.

Didache, w: Pierwsi świadkowie (Biblioteka Ojców Kościoła 10), wstęp. przekład i oprac. M. Starowieyski, Wydawnictwo M, Kraków 2010, s. 33-44.

Dillon R.J., Atti degli Apostoli, w: Nuovo grende commentario biblico, red. R.E. Brown, J.A. Fitzmyer, R.E. Murphy, Queriniana, Brescia 1997, s. 943-1003.

Gerken A., Teologia Eucharystii, tłum. S. Szczyrbowski, Instytut Wydawniczy PAX, Warszawa 1977.

Gigilewicz E., Kościót pierwotny, w: Encyklopedia katolicka, t. IX, red. B. Migut, Towarzystwo Naukowe Katolickiego Uniwersytetu Lubelskiego, Lublin 2002, kol. 1052-1053.

Ginter G., Odnowa w Kościele. Rozważanie oparte na adhortacjach apostolskich Jana Pawła II, http://mateusz.pl/mt/10lat/gg-owk.htm (dostęp: 22.08.2020).

Gryglewicz F., Komentarz do Dz 2,42-47, w: Komentarze biblijne do czytań mszalnych. Rok A, red. J. Homerski, Towarzystwo Naukowe Katolickiego Uniwersytetu Lubelskiego, Lublin 1981, s. 58-59.

Hipolit Rzymski, Tradycja Apostolska, wstęp, przekład, komentarz H. Paprocki, „Studia Theologica Varsaviensia" 14 (1976) nr 1, s. 145-169.

Janicki J.J., Historia Eucharystii w pierwszych wiekach chrześcijaństwa w świetle wybranych źródeł (II-IV w.), „Textus et Studia” 4 (2015) nr 4, s. 95-126.

Jeremias J., Die Abendmahlsworte Jesu, Vandenhoeck \& Ruprecht, Göttingen $1967^{4}$.

Kard. Burke krytykuje teologiczne błędy „Querida Amazonia” https://www.fronda.pl/a/ kard-burke-krytykuje-teologiczne-bledy-querida-amazonia,141247.html (dostęp: 12.03.2020).

Klemens Rzymski, List do Kościoła w Koryncie, w: Pierwsi świadkowie (Biblioteka Ojców Kościoła 10), wstęp, przekład i oprac. M. Starowieyski, Wydawnictwo M, Kraków 2010, s. 51-87.

Konstytucje apostolskie, w: Konstytucje apostolskie oraz Kanony Pamfilosa z apostolskiego synodu w Antiochii, Prawo kanoniczne św. Apostołów, Kary świętych Apostołów dla upadłych, Euchologion Serapiona (Synody i kolekcje praw 2), układ i oprac. A. Baron, H. Pietras, Wydawnictwo WAM, Kraków 2007, s. $1^{\star}-293^{*}$.

Kunzler M., Liturgia Kościoła (Amateca: Podręczniki teologii katolickiej 10), tłum. i oprac. L. Balter, Pallottinum, Poznań 1999.

Leclercq J., U źródeł duchowości Zachodu. Etapy rozwoju i elementy stałe (Źródła monastyczne 49), tłum. S. Sztuka, red. nauk. i posł. T.M. Gronowski, Wydawnictwo Benedyktynów, Kraków-Tyniec 2009. 
Léon-Dufour X., Słownik Nowego Testamentu, przekł. i oprac. K. Romaniuk, Księgarnia Świętego Wojciecha, Poznań 1981.

Lewek A., Objawienie Boże a ewangelizacja według Vaticanum II, „Studia Theologica Varsaviensia” 31 (1993) nr 2, s. 155-195.

Ławreszuk M., Nabożeństwo chrześcijańskie w IV wieku na podstawie „Konstytucji Apostolskich”, „Elpis” 12 (2012), s. 133-153.

Marrou H.I., Od prześladowań za Dioklecjana do śmierci Grzegorza Wielkiego (303-604), w: Historia Kościoła, t. I: Od początków do roku 600, red. J. Daniélou, H.I. Marrou, Instytut Wydawniczy PAX, Warszawa 1986, s. 177-340.

Mickiewicz F., Ewangelia według świętego Łukasza: rozdziały 12-24 (Nowy Komentarz Biblijny III/2), Edycja Świętego Pawła, Częstochowa 2012.

Mnich. Rozmowa $z$ Dom Antoinem Forgeotem OSB, opatem seniorem Fontgomabault, rozm. P. Milcarek, „Christianitas” 70 (2017), s. 107-123.

Nabzdyk Z., Modlitwa - źródło i wyraz duchowości, w: Teologia duchowości katolickiej, red. W. Słomka, M. Chmielewski, J. Misiurek, A.J. Nowak, Redakcja Wydawnictw KUL, Lublin 1993, s 124-147.

Ogólne wprowadzenie do Liturgii Godzin, w: Liturgia Godzin. Codzienna modlitwa ludu Bożego, t. I: Okres Adwentu. Okres Narodzenia Pańskiego, Pallottinum, Poznań 2006, s. 23-98.

Olszewski D., Dzieje chrześcijaństwa w zarysie, Księgarnia św. Jacka, Katowice 1982.

Pliniusz do Trajana, w: Pierwsi świadkowie (Biblioteka Ojców Kościoła 10), wstęp, przekład i oprac. M. Starowieyski, Wydawnictwo M, Kraków 2010, s. 361-363.

Porosło K., Przestrzeń między palcami, https://www.naszczas.pl/duch/przestrzen-miedzy-palcami/ (dostęp: 31.03.2020).

Ratzinger J. / Benedykt XVI, Jezus z Nazaretu, cz. II: Od wjazdu do Jerozolimy do Zmartwychwstania, Jedność, Kielce 2006.

Romaniuk K., Jankowski A., Stachowiak L., Komentarz praktyczny do Nowego Testamentu, t. I, Pallottinum, Poznań-Kraków-Tyniec 1999.

Rubinkiewicz R., Komentarz do Łk 18,9-14, w: Komentarze biblijne do czytań mszalnych. Rok C, red. S. Łach, Towarzystwo Naukowe Katolickiego Uniwersytetu Lubelskiego, Lublin 1981, s. 198-199.

Schneider G., Die Apostelgeschichte, Teil 2: Kommentar zu Kap. 9,1-28,31 (Herders theologischer Kommentar zum Neuen Testament 5), Herder, Freiburg im Breisgau-Basel-Wien 1982.

Sczaniecki P., Msza po staremu się odprawia, Wydawnictwo Benedyktynów, Tyniec-Kraków $2009^{2}$.

Starowieyski M., Dlaczego Kościół starożytny?, https://teologiapolityczna.pl/marek-starowieyski-dlaczego-kosciol-starozytny\#_ftnref1 (dostęp: 14.03.2020).

Starożytność, w: Nowa encyklopedia powszechna PWN, t. VI: S-Z, red. B. Petrozolin-Skowrońska, Wydawnictwo Naukowe PWN, Warszawa 1997, s. 31.

Stypułkowska B., Perspektywy dla dziewic konsekrowanych żyjących w świecie wynikające $z$ duchowości monastycznej, „Analecta Cracoviensia” 48 (2016), s. 195-222. 
Taft R.F., La liturgia delle ore in oriente e occidente. Le origini dell'ufficio e il suo significato per oggi, Edizioni Lipa, Roma 2001.

Żądło A., Pascha Jezusa i jej uobecnienie w liturgii, w: Quod itaque Redemptoris nostri conspicuum fuit, in sacramenta transivit. Sakramenty $w$ misterium Kościoła. Księga dedykowana Księdzu Profesorowi Czesławowi Krakowiakowi z okazji siedemdziesiątych urodzin, red. B. Migut, Z. Głowacki, W. Pałęcki, Wydawnictwo KUL, Lublin 2014, s. 69-80. 